\title{
Effect of Curcumin and Nano-curcumin on Reduce Aluminum Toxicity in Rats
}

\author{
Rehab Mohamed Ibrahim ${ }^{1, ~}$, Fatma El Zahraa Ali Abd Elaal ${ }^{2}$, Sahar Zaki ${ }^{3}$ \\ ${ }^{1}$ Department of Special Food and Nutrition, Food Technology Research Institute, Agricultural Research Center, Giza, Egypt \\ ${ }^{2}$ Department of Horticulture Crops Processing, Food Technology Research Institute, ARC, Giza, Egypt \\ ${ }^{3}$ Environmental Biotechnology Department, Genetic Engineering and Biotechnology Research Institute, City of Scientific Research and \\ Technological Applications, Alexandria, Egypt
}

Email address:

rehabmohamed_eg@yahoo.com (R. M. Ibrahim)

${ }^{*}$ Corresponding author

\section{To cite this article:}

Rehab Mohamed Ibrahim, Fatma El Zahraa Ali Abd Elaal, Sahar Zaki. Effect of Curcumin and Nano-curcumin on Reduce Aluminum Toxicity in Rats. International Journal of Food Science and Biotechnology. Vol. 4, No. 3, 2019, pp. 64-73. doi: 10.11648/j.ijfsb.20190403.12

Received: July 26, 2019; Accepted: August 24, 2019; Published: October 9, 2019

\begin{abstract}
Aluminum is a ubiquitous toxic metal that mainly affects brain, bone, spleen, liver, kidney, hepatic hematopoietic system. This study investigated the effect of Curcumin and Curcumin Nanoparticles on reduced the toxicity of aluminum chloride in treated rats. Six groups of rats were used: (1) control; (2) curcumin-treated rats (15 mg curcumin /Kg BW; (3) Nano-curcumin -treated rats (15 mg Nano-curcumin $/ \mathrm{Kg} \mathrm{BW})$; (4) aluminum chloride-treated rats $\left(100 \mathrm{mg} / \mathrm{kg} \mathrm{BW}\right.$; (5) AlCl${ }_{3}$ curcumin-treated rats $\left(100 \mathrm{mg} \mathrm{AlCl}_{3}\right.$ and $15 \mathrm{mg}$ curcumin $\left./ \mathrm{kg} \mathrm{BW}\right) ;(6) \mathrm{AlCl}_{3}$ - Nano-curcumin -treated rats $(100 \mathrm{mg} \mathrm{AlCl} 3$ and $15 \mathrm{mg}$ Nano-curcumin $/ \mathrm{kg} \mathrm{BW})$. The treatment with $\mathrm{AlCl}_{3}$ alone caused significant $(\mathrm{P} \leq 0.05)$ increased in liver and kidney functions of rats, while the oral intake of curcumin and Nano-curcumin eliminate the harmful effect of $\mathrm{AlCl}_{3}$. On the same side, the treatment with $\mathrm{AlCl}_{3}$ alone significantly $(\mathrm{P} \leq 0.05)$ increase the free radical level and decreased the activities of antioxidant enzymes in plasma, while the treatment with curcumin and Nano-curcumin reduced this increased in free radicals and increased the activities of antioxidant enzymes. These results confirmed that the curcumin and Nano-curcumin reduced the toxicity effect of $\mathrm{AlCl}_{3}$ in rats; moreover, Nano-curcumin has a best biological and antioxidant activity than curcumin in healthy and $\mathrm{AlCl}_{3}$-treated rats.
\end{abstract}

Keywords: Curcumin, Nano-curcumin, Aluminum Toxicity, Nano-Toxicology

\section{Introduction}

Curcumin is the most active polyphenol compound in the rhizome of turmeric (Curcuma longa). Curcumin is known as a strong anti-inflammatory, antioxidant, antimutagenic, wound healing, neuroprotective, hypoglycemic, antimicrobial, antitumor, tissue regenerating, antiangiogenic,, anti-metastatic [1]. In addition, curcumin exhibits many pharmacological activities against many chronic diseases such as type 2 diabetes, multiple sclerosis, rheumatoid arthritis, Alzheimer's disease, suppresses thrombosis and inhibits human immunodeficiency virus (HIV) replication, enhances wound healing and protects against liver injury, anticancer (breast, colon, cervical, stomach, pancreatic and liver cancer) with low or no intrinsic toxicity to healthy cells [2]. The effectiveness of curcumin therapy, however, is limited by its low oral bioavailability caused by its poor solubility in the gastrointestinal fluid, rapid degradation at the intestinal $\mathrm{pH}$ and rapid metabolism [3]. An obvious process to improve the poor biopharmaceutical properties of curcumin is to improve its solubility in water using nanocarriers. Nanocarriers have a small size (typically 10-100 nm) and can, besides for solubilization. The Nano-sizing of curcumin particles increases their bioavailability and, therefore, their efficacy in a possible clinical application [4]. Aluminum (Al) is the third most abundant metal and constitutes about $8 \%$ of the earth crust [5]. Aluminum exposed through a wide range of household items, cooking utensils, food additives, water treatment, foods, packaging, vaccines, pharmaceuticals, and a numerous medication such as antidiarrheal agents, antacids, 
phosphate binders, antiperspirants, buffer aspirin as well as a few, cosmetics are important sources of $\mathrm{Al}$ for humans $[6,7]$. Today the daily ingested dose via drinking water is estimated to be around $160 \mu \mathrm{g}$ aluminum/day, high as $3500-5200 \mathrm{mg}$ aluminum/day (i.e. $50 \mathrm{mg} / \mathrm{kg} /$ day- $75 \mathrm{mg} / \mathrm{kg} /$ day) as a result of aluminum-based antacid consumption [8]. Aluminium is a ubiquitous toxic metal that mainly affects brain, bone, spleen, liver, kidney, hepatic hematopoietic system, central nervous, skeletal, hematopoietic systems, respiratory, immunologic system [6]. Aluminum has been shown to have the potential to be a toxicant to the Toxicity to system of Al is also drawn an attention recently [9]. Aluminium is neurotoxic in humans body and has been implicated in several neurological disorders, like Alzheimer's disease, Parkinsonism and dialysis encephalopathy, microcytic hypochromic anemia and osteomalacia, in renal osteodystrophy, anaemia, breast cancer and autoimmune (auto-inflammatory) syndrome induced by vaccination $[10,11]$. It has been reported that Al-induced toxication is associated with anemia in humans and in animals [12]. The objective of this study was to evaluate the effect of curcumin and Nano-curcumin on reduce the toxicity in aluminum-treated rats.

\section{Materials and Methods}

\subsection{Material}

Curcumin powder was obtained from Hi-Media Laboratories Ltd., Mumbai, India. Aluminum chloride was obtained from Loba Chemie, Mumbai, India (orally administered by $100 \mathrm{mg} / \mathrm{kg}$, according to Chiroma et al. [13]. Reduced glutathione; 5, 5-dithiobis (2-nitrobenzoic acid) (DTNB); Sulfosalisilic acid (SSA); and Thiobarbituric acid (TBA) were obtained from Sigma- Aldrich. Co, Saint Louis, USA. Urea and Creatinine kits were obtained from Biosystems, Spain; Bilirubin kit was obtained from Diamond, Germany; AST, ALT kits were obtained from QUIMICA CLINICA APLICADA, Spain; and ALP, ACP kits were obtained from Biodiagnostic, Egypt.

\subsection{Methods}

\subsubsection{Synthesis and Characterization of Curcumin Nanoparticles}

Curcumin solution $(5 \mathrm{mg} / \mathrm{ml})$ was prepared by dissolving $100 \mathrm{mg}$ curcumin powder in $20 \mathrm{ml}$ Dichloromethane. One $\mathrm{ml}$ of stock solution was added to boiling water $(50 \mathrm{ml})$ in dropwise manner under ultra-sonication condition with an ultrasonic power and frequency of $50 \mathrm{kHz}$. The solution was sonicated for $30 \mathrm{~min}$. After sonication, the mixture was stirred at $800 \mathrm{rpm}$ for about $20 \mathrm{~min}$ till the orange colored precipitate was obtained. Thereafter, supernatant was discarded and the pellet obtained was used for further biological study. The obtained particles were characterization using Infrared spectroscopy (FTIR-8400S, Shimadzu, Japan) and electron microscopy (JEOL JEM-1230, Japan).

\subsubsection{Experimental Design}

Forty-eight male albino rats (7 weeks old and 158-169 g weight) obtained from the Institute of Graduate Studies and Research (IGSR), Alexandria University, Egypt. The design of the experiment was approved by the local committee in Alexandria University, Egypt, according to the protocol conforms to the guidelines of the National Institutes of Health (NIH). were dwelled plastic cages (4/cage) with sawdust bedding and maintained in an air-conditioned animal house at a controlled temperature $\left(22 \pm 2{ }^{\circ} \mathrm{C}\right)$ and relative humidity $(60 \pm 10 \%)$ with a photoperiod of $12 \mathrm{~h}$ light $/ 12 \mathrm{~h}$ dark [14]. After two weeks of acclimatization, the animals were divided into six equal groups, 8 animals in each group. Group 1 was used as a control. Group 2 was daily orally treated with curcumin by $15 \mathrm{mg} / \mathrm{Kg} \mathrm{BW}$ in $0.1 \% \mathrm{DMSO}$ [15]. Groups 3 was daily orally treated with Nano-curcumin $15 \mathrm{mg} / \mathrm{kg} \mathrm{BW}$ in distilled water [15]. Group 4 was daily orally administered aluminum chloride $100 \mathrm{mg} / \mathrm{kg} \mathrm{BW}$ in distilled water [13]. Groups 5 and 6 were treated with $\mathrm{AlCl}_{3}$ solution $(100 \mathrm{mg} / \mathrm{kg} \mathrm{BW})$ plus orally given curcumin and Nano-curcumin (15 mg / Kg BW) respectively. Animals were daily treated with the tested aluminum chloride, curcumin and Nano-curcumin juice for 30 day. All treatment was administered daily as an oral dose using a gastric tube.

\subsubsection{Feed and Water Intake}

Feed and water intake were recorded throughout the experimental period, and mean daily feed and water intake were determined.

\subsubsection{Body Weight}

At first and end of the experimental period, body weights of rats were recorded.

\subsubsection{Hematological Parameters}

At the end of the experimental period (after 30 days) rats were anesthetized with ether and sacrificed and the blood samples were collected in two tubes: one containing EDTA (anti-coagulant) and the other containing Heparin (anticoagulant). Non coagulated blood by EDTA was tested shortly after collection by Particle counter (from ERMA INC.-Tokyo. Model PCE-210) for measuring total erythrocyte count (TEC) red blood cells (RBC), hemoglobin $(\mathrm{Hb})$, hematocrit $(\mathrm{Ht})$, platelets count (PLT), red cell distribution width (RDW), mean cell volume (MCV), mean corpuscular hemoglobin concentration $(\mathrm{MCHC})$ and mean corpuscular hemoglobin $(\mathrm{MCH})$. Total leukocyte counts (TLC) white blood cell count (WBC), lymphocytes, segmented neutrophils, monocytes and eosinophils.

\subsubsection{Blood Biochemical Parameters and Enzyme Activities}

The other part of heparinized blood samples were placed immediately on ice. Plasma was obtained by centrifugation of samples at $4000 \mathrm{rpm}$ for $20 \mathrm{~min}$, and was stored at $-80^{\circ} \mathrm{C}$ until used for analyses.

\section{(i). Kidney Function}

kidney functions were evaluated by measuring of serum levels of blood urea according to Tabacco et al. [16], total 
bilirubin concentration according to Burtis et al. [17] and creatinine concentration was measured by the method of Fabiny and Ertingshausen [18] using commercial Kits.

\section{(ii). Liver Function}

The activities of plasma alanine transaminase (ALT) and aspartate transaminase (AST) were assayed by the method of Reitman and Frankel [19]. Alkaline phosphatase (AlP) activity and Acid Phosphatase (AcP) were determined in plasma according to the method of Belfield and Goldberg [20]; and Kind and King [21], respectively.

\subsubsection{Antioxidant Activity}

Plasma free radical was measured by thiobarbituric acidreactive substances (TBARS) assay based on the method of Tappel and Zalkin [22]. Superoxide dismutase (SOD) and Glutathione S-transferase (GST) activities in plasma were determined according to the method of Misra and Fridovich [23]; and Habig et al. [24], respectively. Meanwhile, the concentration of Glutathione reduced (GSH) was determined according to the method of Jollow et al. [25].

\subsubsection{Statistical Analysis}

The data were analyzed by a general linear model procedure of the Fisher's protected least-significant difference (PLSD) test using SAS, 2004. The differences among the means of all treatments at the significance level of $P \leq 0.05$. Correlations were calculated using Pearson's correlation coefficient [26].

\section{Results and Discussion}

\subsection{Characterization of Nano Curcumin}

\subsubsection{FTIR Spectrum of Curcumin Nanoparticles Powder}

FTIR spectrum of curcumin in DMSO (control) and Nanocurcumin (experimental) was recorded. In FTIR spectrum of Nano-curcumin, peaks were observed at 1633, 1442, 1153 and $1033 \mathrm{~cm}^{-1}$ (Figure 1).

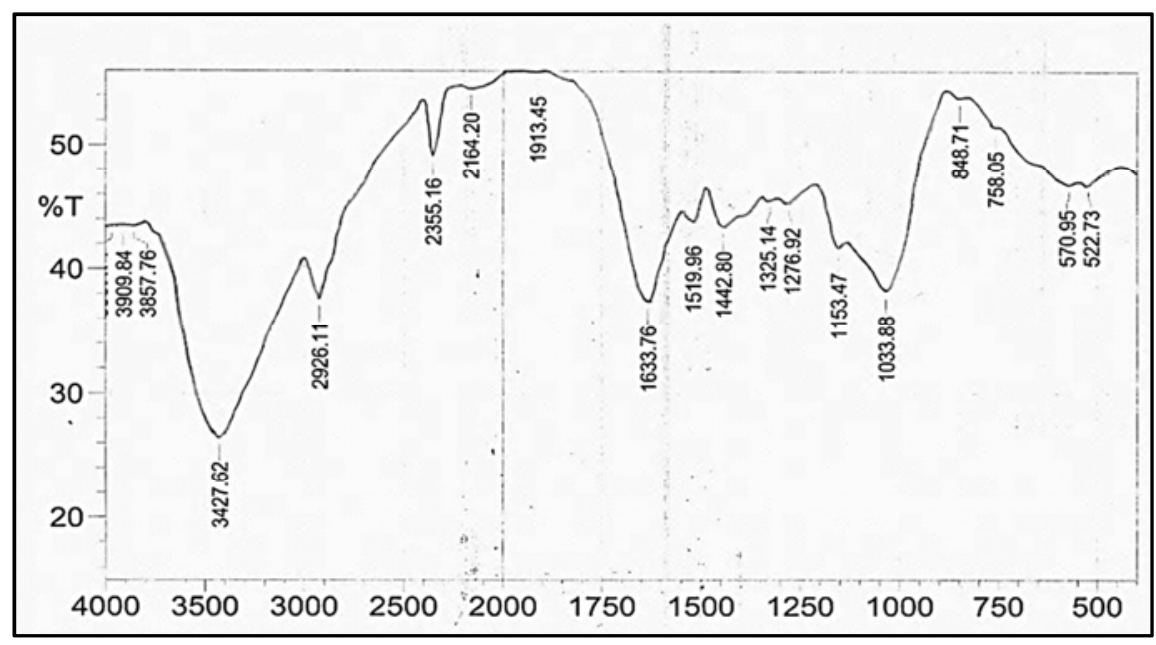

Figure 1. FTIR spectrum of curcumin nanoparticles.

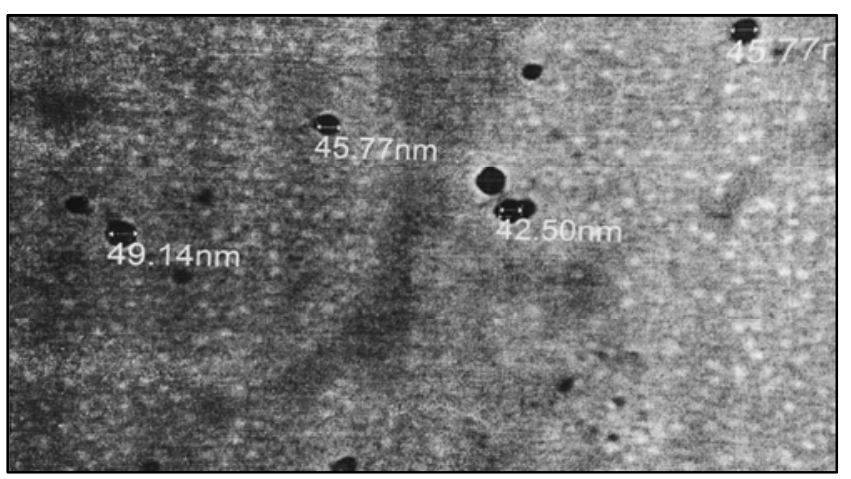

Figure 2. Scanning electron microphotographs (SEM) of curcumin nanoparticles.

\subsubsection{Scanning Electron Microscopy (SEM) of Curcumin Nanoparticles}

Scanning Electron Microscopy (SEM) is a very helpful tool for explore morphology of nanoparticles powders. SEMimages of the nanoparticles prepared via wet chemical route. It is unclouded that the nanoparticles apparent by SEMimage consist of a number of crystallites with rutile structure. SEMimages of the Curcumin nanoparticles (Figure 2) show that they are approximately in globular form and sizes are various $(<100 \mathrm{~nm})$.

\subsection{Changes in Feed and Water Intake, Initial and Final Body Weight, and Body Weight Gain}

Data presented in Table 1 showed the effect of curcumin and Nano-curcumin on the body weight, body weight gain, feed intake and water intake of rats treated with aluminum chloride. No significant $(P \geq 0.05)$ differences were found between all groups in all previous parameters. These results confirmed that there was no effect of $\mathrm{Al} \mathrm{Cl}_{3}$ on body weight and feeding of rats. These results agree with Kumar [27] who reported that treatment with oral aluminum chloride resulted not affected on weight of adult rats when treated for 60 days. Meanwhile, Abubakar et al. [28] found that the treated with aluminum alone had a reduced rate of weight gain that was attributed to decreased food intake. 
Table 1. Effect of curcumin, nano curcumin on initial and final body weight, body weight gain, feed intake and water intake of rats treated with aluminum chloride.

\begin{tabular}{lllllll}
\hline \multirow{2}{*}{ Parameters } & Experimental groups & & & \\
& Control & Curcumin & Nano-curcumin & $\mathbf{A l C l}_{3}$ & $\mathbf{A l C l}_{3}+$ curcumin & AlCl $_{3}+\mathbf{N a n o}^{\mathrm{a}}$ curcumin \\
\hline Initial body weight (g) & $160 \pm 6.7^{\mathrm{a}}$ & $158 \pm 7.2^{\mathrm{a}}$ & $161 \pm 7.0^{\mathrm{a}}$ & $169 \pm 4.3^{\mathrm{a}}$ & $160 \pm 8.9^{\mathrm{a}}$ & $160 \pm 6.5^{\mathrm{a}}$ \\
& & $(-1)^{*}$ & $(1)^{*}$ & $(6)^{*}$ & $(0)^{*}$ & $(0)^{*}$ \\
Final body weight (g) & $181 \pm 5.8^{\mathrm{a}}$ & $182 \pm 4.1^{\mathrm{a}}$ & $183 \pm 8.5^{\mathrm{a}}$ & $191 \pm 4.3^{\mathrm{a}}$ & $184 \pm 4.8^{\mathrm{a}}$ & $185 \pm 9.5^{\mathrm{a}}$ \\
& & $(1)^{*}$ & $(1)^{*}$ & $(6)^{*}$ & $(2)^{*}$ & $(2)^{*}$ \\
Body weight gain (g/day) & $0.702 \pm 0.0692^{\mathrm{a}}$ & $0.809 \pm 0.0499^{\mathrm{a}}$ & $0.733 \pm 0.0481^{\mathrm{a}}$ & $0.734 \pm 0.0516^{\mathrm{a}}$ & $0.812 \pm 0.0359^{\mathrm{a}}$ & $0.833 \pm 0.0405^{\mathrm{a}}$ \\
& & $(15)^{*}$ & $(4)^{*}$ & $(5)^{*}$ & $(17)^{*}$ & $(19)^{*}$ \\
Feed intake (g/day/kg BW) & $161 \pm 6.6^{\mathrm{a}}$ & $165 \pm 4.2^{\mathrm{a}}$ & $161 \pm 3.5^{\mathrm{a}}$ & $166 \pm 8.4^{\mathrm{a}}$ & $164 \pm 8.4^{\mathrm{a}}$ & $168 \pm 5.5^{\mathrm{a}}$ \\
& & $(3)^{*}$ & $(0)^{*}$ & $(3)^{*}$ & $(2)^{*}$ & $(4)^{*}$ \\
Water intake (ml/day/kg BW) & $77.7 \pm 3.31^{\mathrm{a}}$ & $75.3 \pm 3.38^{\mathrm{a}}$ & $73.6 \pm 3.12^{\mathrm{a}}$ & $78.7 \pm 3.30^{\mathrm{a}}$ & $76.7 \pm 2.89^{\mathrm{a}}$ & $76.6 \pm 2.46^{\mathrm{a}}$ \\
\hline
\end{tabular}

Values are expressed as means $\pm \mathrm{SE} ; \mathrm{n}=5$ for each treatment group.

Mean values within a row not sharing a common superscript letter (a) were significantly different, $p<0.05$. *percentage of control group.

\subsection{Effect of Curcumin, Nano-Curcumin on Hematological Parameters of Rats Treated with Aluminum Chloride}

Effect of curcumin, Nano-curcumin on hematological parameters of rats treated with aluminum chloride was present in Table 2. The treatment with aluminum chloride alone caused significant $(\mathrm{P} \geq 0.05)$ decrease in $\mathrm{RBC}, \mathrm{HB} \%$, $\mathrm{RDW} \%$ and $\mathrm{MCH}$ of rats, while, the treatment with curcumin and Nano-curcumin reduced the decrease in these parameters. Concerning HT, PLT, MCV and MCHC, no significant $(\mathrm{P} \geq 0.05)$ changes were found after treated with aluminum chloride alone, curcumin and Nano-curcumin alone or with aluminum chloride treatment in compared with control group. This result agrees with this of Mahieu et al. [12], he indicated that Al-induced toxicities are associated with anemia in humans and in animals. Moreover, plasma $\mathrm{Fe}$ levels were significantly lower in the Aluminum-treated rats than that in control. Zhang et al. [29] reported that the increase of Al levels in the blood could destroy the structure and disorder functions of red blood cells, and caused hematological diseases. The binding of $\mathrm{Al}$ with erythrocytes was much stronger than to serum proteins, the half retention time of $\mathrm{Al}$ in red blood cell is ranging from 20 to 40 days [30]. Moreover, aluminum chloride suppressed the immune function of red blood cells of mice [31]. Zhang et al. [32] found that $\mathrm{AlCl}_{3}$ unrest the structure of erythrocyte membrane and incourage hypertension in rat. Meanwhile, the treatment of rats with $\mathrm{Al} \mathrm{Cl}_{3}$ alone caused significant increase in monocytes \%, while the oral intake of curcumin and Nanocurcumin not affected on monocytes $\%$ of $\mathrm{AlCl}_{3}$-treated rats (Table 3). On the other side, No significant $(\mathrm{P} \geq 0.05)$ changes were found in WBC, Lymphocytes (\%), Neutrophils (\%) and eosinophils of all rats groups whether treated with $\mathrm{AlCl}_{3}$ alone or $\mathrm{AlCl}_{3}$ with curcumin and Nano-curcumin.

Table 2. Effect of curcumin, nano curcumin on hematological parameters of rats treated with aluminum chloride.

\begin{tabular}{|c|c|c|c|c|c|c|}
\hline \multirow{2}{*}{ Parameters } & \multicolumn{6}{|c|}{ Experimental groups } \\
\hline & Control & Curcumin & Nano- curcumin & $\mathbf{A l C l}_{3}$ & $\mathrm{AlCl}_{3}+$ curcumin & $\mathrm{AlCl}_{3}+$ Nano- curcumin \\
\hline $\mathrm{RBC}\left(\mathrm{x} 10^{6} / \mu \mathrm{l}\right)$ & $7.54 \pm 0.158^{\mathrm{ab}}$ & $\begin{array}{l}7.55 \pm 0.611^{\mathrm{ab}} \\
(0)^{*}\end{array}$ & $\begin{array}{l}7.64 \pm 0.221^{\mathrm{a}} \\
(1)^{*}\end{array}$ & $\begin{array}{l}6.44 \pm 0.384^{b} \\
(-15)^{*}\end{array}$ & $\begin{array}{l}6.90 \pm 0.404^{\mathrm{ab}} \\
(-8)^{*}\end{array}$ & $\begin{array}{l}7.15 \pm 0.178^{a b} \\
(-5)^{*}\end{array}$ \\
\hline $\mathrm{Hb}(\mathrm{g} / \mathrm{dl})$ & $11.7 \pm 0.33^{\mathrm{a}}$ & $\begin{array}{l}11.7 \pm 1.14^{\mathrm{a}} \\
(0)^{*}\end{array}$ & $\begin{array}{l}11.8 \pm 0.44^{\mathrm{a}} \\
(1)^{*}\end{array}$ & $\begin{array}{l}9.64 \pm 0.214^{b} \\
(-17)^{*}\end{array}$ & $\begin{array}{l}10.7 \pm 0.73^{\mathrm{ab}} \\
(-9)^{*}\end{array}$ & $\begin{array}{l}10.9 \pm 0.36^{\mathrm{ab}} \\
(-7)^{*}\end{array}$ \\
\hline Ht (\%) & $33.1 \pm 1.56^{\mathrm{a}}$ & $\begin{array}{l}36.1 \pm 2.76^{\mathrm{a}} \\
(0)^{*}\end{array}$ & $\begin{array}{l}36.1 \pm 0.45^{\mathrm{a}} \\
(0)^{*}\end{array}$ & $\begin{array}{l}30.8 \pm 1.59^{\mathrm{a}} \\
(-15)^{*}\end{array}$ & $\begin{array}{l}32.7 \pm 1.9^{\mathrm{a}} \\
(-9)^{*}\end{array}$ & $\begin{array}{l}33.1 \pm 0.8^{\mathrm{a}} \\
(-8)^{*}\end{array}$ \\
\hline RDW (\%) & $18.0 \pm 0.54^{\mathrm{a}}$ & $\begin{array}{l}18.0 \pm 0.79^{\mathrm{a}} \\
(0)^{*}\end{array}$ & $\begin{array}{l}18.0 \pm 0.88^{\mathrm{a}} \\
(0)^{*}\end{array}$ & $\begin{array}{l}15.6 \pm 0.37^{b} \\
(-13)^{*}\end{array}$ & $\begin{array}{l}16.9 \pm 0.85^{\mathrm{ab}} \\
(-6)^{*}\end{array}$ & $\begin{array}{l}17.1 \pm 0.69^{\mathrm{ab}} \\
(-5)^{*}\end{array}$ \\
\hline $\operatorname{MCV}(\mathrm{fl})$ & $67.5 \pm 2.62^{\mathrm{a}}$ & $\begin{array}{l}67.6 \pm 2.16^{\mathrm{a}} \\
(0)^{*}\end{array}$ & $\begin{array}{l}68.0 \pm 3.90^{\mathrm{a}} \\
(1)^{*}\end{array}$ & $\begin{array}{l}60.0 \pm 6.12^{\mathrm{a}} \\
(-11)^{*}\end{array}$ & $\begin{array}{l}64.5 \pm 1.50^{\mathrm{a}} \\
(-4)^{*}\end{array}$ & $\begin{array}{l}66.0 \pm 2.12^{\mathrm{a}} \\
(-2)^{*}\end{array}$ \\
\hline $\mathrm{MCH}(\mathrm{pg})$ & $21.1 \pm 0.44^{\mathrm{ab}}$ & $\begin{array}{l}21.2 \pm 1.28^{\mathrm{ab}} \\
(1)^{*}\end{array}$ & $\begin{array}{l}22.0 \pm 1.74^{\mathrm{a}} \\
(4)^{*}\end{array}$ & $\begin{array}{l}18.0 \pm 0.71^{\mathrm{c}} \\
(-14)^{*}\end{array}$ & $\begin{array}{l}18.6 \pm 0.21^{b c} \\
(-12)^{*}\end{array}$ & $\begin{array}{l}20.1 \pm 0.43^{\mathrm{abc}} \\
(-5)^{*}\end{array}$ \\
\hline
\end{tabular}

Values are expressed as means $\pm \mathrm{SE} ; \mathrm{n}=5$ for each treatment group.

Mean values within a row not sharing a common superscript letters ( $\mathrm{a}, \mathrm{b}, \mathrm{c})$ were significantly different, $\mathrm{p}<0.05$. RBC $=$ red blood cells; Hb $=$ hemoglobin; $\mathrm{Ht}$ $=$ hematocrit PLT $=$ platelets count $\mathrm{RDW}=$ red cell distribution width; $\mathrm{MCV}=$ mean cell volume; $\mathrm{MCH}=$ mean corpuscular hemoglobin and $\mathrm{MCHC}=$ mean corpuscular hemoglobin concentration.

*percentage of control group. 
Table 3. Effect of curcumin, nano curcumin on white blood cell count (WBC) and differential counts of rats treated with aluminum chloride.

\begin{tabular}{|c|c|c|c|c|c|c|}
\hline \multirow{2}{*}{ Parameters } & \multicolumn{6}{|c|}{ Experimental groups } \\
\hline & Control & Curcumin & Nano-curcumin & $\mathrm{AlCl}_{3}$ & $\mathrm{AlCl}_{3}+$ curcumin & $\mathrm{AlCl}_{3}+$ Nano-curcumin \\
\hline $\mathrm{WBC}\left(\mathrm{x} 10^{3} / \mu \mathrm{l}\right)$ & $8.60 \pm 0.2000^{\mathrm{a}}$ & $\begin{array}{l}8.35 \pm 0.709^{a} \\
(-3)^{*}\end{array}$ & $\begin{array}{l}8.25 \pm 0.594^{a} \\
(-4)^{*}\end{array}$ & $\begin{array}{l}9.20 \pm 0.456^{\mathrm{a}} \\
(7)^{*}\end{array}$ & $\begin{array}{l}8.95 \pm 0.430^{\mathrm{a}} \\
(4)^{*}\end{array}$ & $\begin{array}{l}8.80 \pm 1.329^{\mathrm{a}} \\
(2)^{*}\end{array}$ \\
\hline Lymphocytes (\%) & $75.5 \pm 1.80^{\mathrm{a}}$ & $\begin{array}{l}75.2 \pm 3.87^{\mathrm{a}} \\
(0)^{*}\end{array}$ & $\begin{array}{l}75.2 \pm 3.46^{\mathrm{a}} \\
(0)^{*}\end{array}$ & $\begin{array}{l}78.0 \pm 3.59^{\mathrm{a}} \\
(3)^{*}\end{array}$ & $\begin{array}{l}77.0 \pm 3.81^{\mathrm{a}} \\
(2)^{*}\end{array}$ & $\begin{array}{l}76.5 \pm 2.30^{\mathrm{a}} \\
(1)^{*}\end{array}$ \\
\hline Neutrophils (\%) & $19.4 \pm 1.50^{\mathrm{a}}$ & $\begin{array}{l}19.3 \pm 1.04^{\mathrm{a}} \\
(-1)^{*}\end{array}$ & $\begin{array}{l}19.2 \pm 1.24^{\mathrm{a}} \\
(-1)^{*}\end{array}$ & $\begin{array}{l}19.4 \pm 1.44^{\mathrm{a}} \\
(0)^{*}\end{array}$ & $\begin{array}{l}19.4 \pm 1.72^{\mathrm{a}} \\
(0)^{*}\end{array}$ & $\begin{array}{l}19.3 \pm 1.16^{\mathrm{a}} \\
(-1)^{*}\end{array}$ \\
\hline Monocytes (\%) & $4.00 \pm 0.707^{b}$ & $\begin{array}{l}4.00 \pm 0.548^{\mathrm{b}} \\
(0)^{*}\end{array}$ & $\begin{array}{l}3.90 \pm 0.678^{b} \\
(-3)^{*}\end{array}$ & $\begin{array}{l}5.80 \pm 0.583^{\mathrm{a}} \\
(45)^{*}\end{array}$ & $\begin{array}{l}5.30 \pm 0.539^{\mathrm{a}} \\
(33)^{*}\end{array}$ & $\begin{array}{l}5.30 \pm 0.831^{\mathrm{a}} \\
(33)^{*}\end{array}$ \\
\hline Eosinophils (\%) & $3.20 \pm 0.148^{\mathrm{a}}$ & $\begin{array}{l}3.20 \pm 0.182^{\mathrm{a}} \\
(0)^{*}\end{array}$ & $\begin{array}{l}3.22 \pm 0.174^{\mathrm{a}} \\
(-1)^{*}\end{array}$ & $\begin{array}{l}3.00 \pm 0.158^{\mathrm{a}} \\
(-6)^{*}\end{array}$ & $\begin{array}{l}3.02 \pm 0.049^{\mathrm{a}} \\
(-6)^{*}\end{array}$ & $\begin{array}{l}3.04 \pm 0.172^{\mathrm{a}} \\
(-5)^{*}\end{array}$ \\
\hline
\end{tabular}

Values are expressed as means $\pm \mathrm{SE} ; \mathrm{n}=5$ for each treatment group.

Mean values within a row not sharing a common superscript letters $(a, b)$ were significantly different, $p<0.05$.

*percentage of control group.

\subsection{Kidney Functions of Rats}

The effect of curcumin and Nano-curcumin on kidney function of rats treated with $\mathrm{AlCl}_{3}$ was present in Figure 3. The treatment with $\mathrm{AlCl}_{3}$ alone caused significant $(\mathrm{P} \leq 0.05)$ increased in urea, creatinine, and bilirubin of rats, while the oral intake of curcumin and Nano-curcumin eliminate the harmful effect of $\mathrm{AlCl}_{3}$ on kidney functions of rats. The treatment with curcumin and Nano-curcumin not affected on kidney functions of healthy rats compared with control group. No significant $(\mathrm{P} \geq 0.05)$ differences were found in

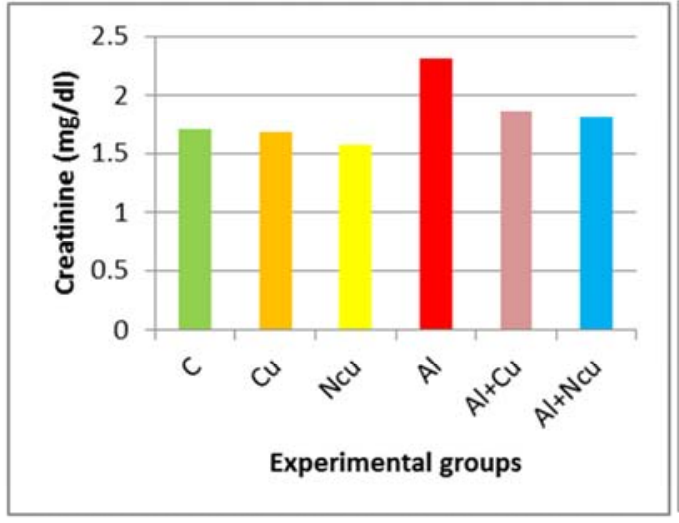

(A) kidney functions between Aluminum groups treated with curcumin and Nano-curcumin. The increased in urea and creatinine levels is indicate protein catabolism and/or kidney dysfunction [33]. The last studies reported that curcumin has therapeutic potential against renal diseases and nephroprotective activity [34]. Inaddition, curcumin has been reported to exert nephroprotective effects on renal damage of several experimental models, such as those of cisplatin, acetaminophen, nephrectomy, gentamicin [34].

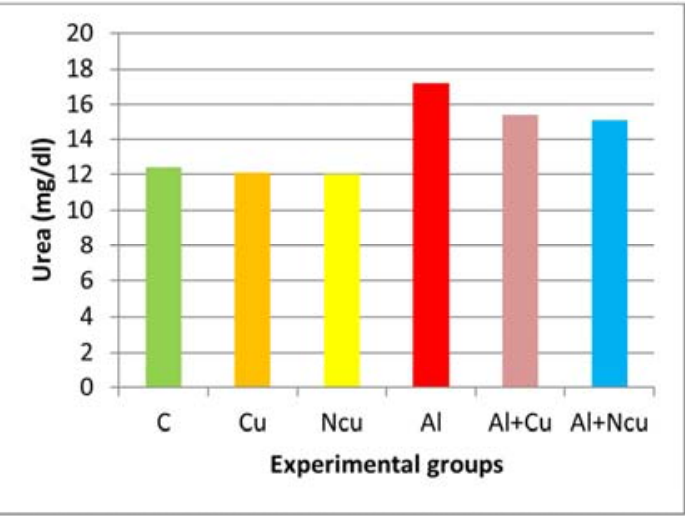

(B)

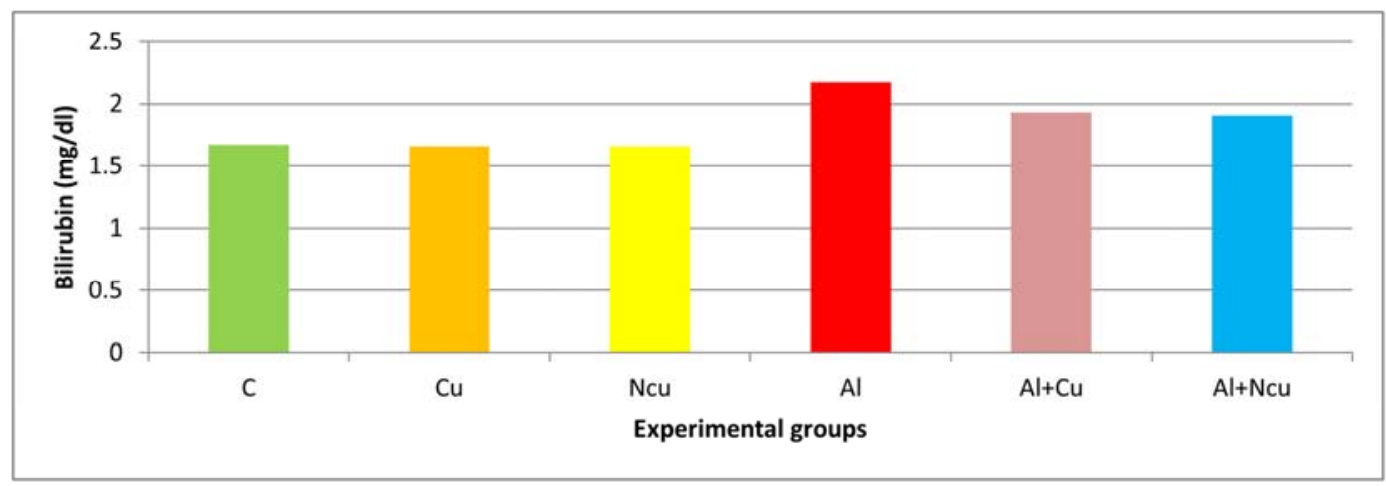

(C)

Figure 3. Effect of curcumin, nano-curcumin on kidney functions of rats treated with aluminum chloride.

$\mathrm{C}$ : Control, $\mathrm{Cu}$ : curcumin, $\mathrm{Ncu}$ : nano-curcumin, $\mathrm{Al}$ : aluminum chloride, $\mathrm{Al}+\mathrm{Cu}$ : aluminum chloride + curcumin and $\mathrm{Al}+\mathrm{Ncu}:$ aluminum chloride $+\mathrm{Nano}-$ curcumin 


\subsection{Liver Functions of Rats}

Liver is the site that toxic compounds get transformed into less harmful products to reduce toxicity; this will damage hepatocytes and produce hepatotoxicity [35]. Toxicity to hepatic system of $\mathrm{Al}$ is also drawn an attention recently [9]. In this study the treatment with $\mathrm{AlCl}_{3}$ alone significantly $(\mathrm{P} \leq$ 0.05) increased the ALT, AST, ALP and ACP values in blood plasma of rats (Figure 4). The treatment with curcumin and Nano-curcumin showed protective effect of the liver function whereas that treated or not treated with $\mathrm{AlCl}_{3}$. The oral intake of curcumin and Nano-curcumin decreased the increase in ALT, AST, ALP and ACP values of rats treated with $\mathrm{AlCl}_{3}$. The effect of curcumin on liver enzyme was similar that of Nano-curcumin whether in normal or Aluminum- treated rats. These results are agree with $\mathrm{Xu}$ et al. [35] who reported that $\mathrm{AlCl}_{3}$ exposure increased serum AST and ALT activities and caused liver histopathological lesion. The previous studies suggested that when the liver is injured, AST and ALT increased and released into peripheral blood, thus serum AST and ALT are recognized as the principal indicators of liver injury [36]. The significant increase in serum AST and ALT, indicating that $\mathrm{AlCl}_{3}$ exposure leads to increased permeability, damage and/or necrosis of hepatocytes [35]. In the same way, Turkez et al. [37] reporting that after the oral intake of $\mathrm{AlCl}_{3}$ (34 mg/kg body weight), serum AST and ALT are increased. Rats treated with Curcumin- $\mathrm{AlCl}_{3}$ and Nanocurcumin- $\mathrm{AlCl}_{3}$ was comparable to the control group regarding ALT, AST, ALP and ACP. This result was agreed with Abdel-Wahhab et al. [38]. Those found the oral administration with curcumin and Nano-curcumin decreased the toxicity effect of $\mathrm{Hg}$ in the liver of rats.

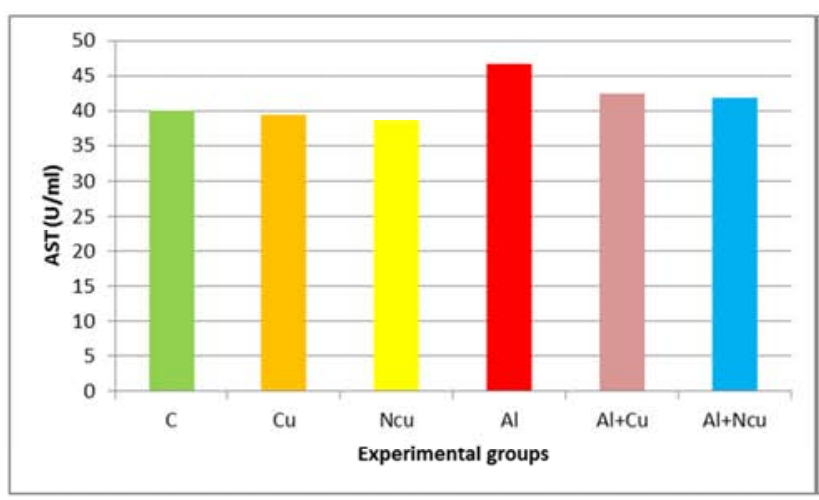

(A)

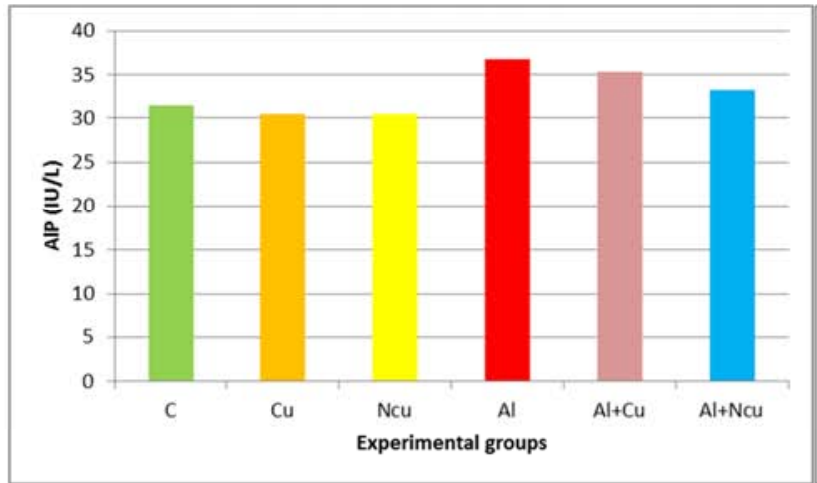

(C)

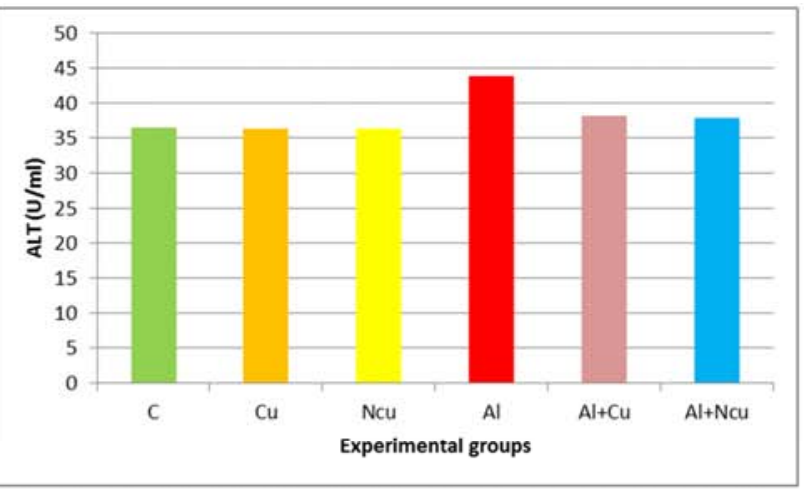

(B)

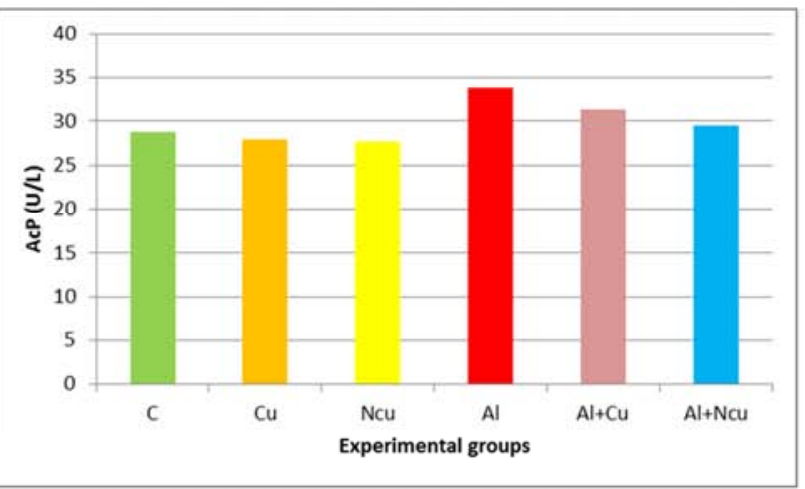

(D)

Figure 4. Effect of curcumin, nano curcumin on liver function of rats treated with aluminum chloride.

$\mathrm{C}$ : Control, $\mathrm{Cu}$ : curcumin, $\mathrm{Ncu}$ : nano-curcumin, $\mathrm{Al}$ : aluminum chloride, $\mathrm{Al}+\mathrm{Cu}$ : aluminum chloride + curcumin and $\mathrm{Al}+\mathrm{Ncu}:$ aluminum chloride $+\mathrm{Nano}-$ curcumin

\subsection{Effect of Curcumin, Nano Curcumin on TBARS and Antioxidant Enzymes of Male Rats Treated with Aluminum Chloride}

Oxidative stress is known as one of the important mechanisms of $\mathrm{Al}$ toxicity. $\mathrm{Al}$ induces oxidative stress through three pathways. First pathway, pro-oxidant activity, due to the formation of $\mathrm{Al}$ superoxide complex between $\mathrm{Al}_{3}{ }^{+}$ and superoxide radical anion, promoting biological oxidation both in vitro and in vivo [39]. Second pathway, reducing ferric iron to ferrous iron, which would promote Fenton reaction in vivo systems, increasing the concentration of free radicals, such as hydroxyl radical [40]. Third pathway, Al facilitates the production of superoxide anion through noniron driven biological oxidations involving the photochemical, enzymatic, and chemical and bio-molecular 
[41]. The effect of oral intake of curcumin and Nanocurcumin on antioxidant activity in plasma of rats treated with $\mathrm{AlCl}_{3}$ in additionally healthy rats was presented in (Figure 5). The treatment with $\mathrm{AlCl}_{3}$ alone significantly $(\mathrm{P} \leq$ $0.05)$ increase TBARS values in rats plasma, while the treatment with curcumin and Nano-curcumin reduced the increase in TBARS in $\mathrm{AlCl}_{3}$ groups. Also, the oral administration of healthy rats with curcumin and Nanocurcumin decreased TBARS values than control group. $\mathrm{AlCl}_{3}$ treatment caused significant $(\mathrm{P} \leq 0.05)$ decrease in SOD, GST activities in plasma. The oral intake of curcumin and Nanocurcumin protected the activity of SOD and GST activities and reduced the decrease in $\mathrm{AlCl}_{3}$ groups. Concerning GSH concentration in healthy and $\mathrm{AlCl}_{3}$ groups, the results showed a significant $(\mathrm{P} \leq 0.05)$ decrease in $\mathrm{GSH}$ value after treated with $\mathrm{AlCl}_{3}$. Curcumin and Nano-curcumin improvement GSH value in healthy rats compared to control group, and reduced the decreased in $\mathrm{AlCl}_{3}$ groups. Nano-curcumin showed best antioxidant activity than curcumin in healthy and $\mathrm{AlCl}_{3}$ groups. These results agrees with Bihaqi et al. [42] who's reported that the treatment with $\mathrm{AlCl}_{3}$ cause a significant decrease in of GST and GPX activities, meanwhile SOD activity was increased in compared with control. Also, $\mathrm{AlCl}_{3}$ treatment caused significant decreased in the GSH concentration in plasma. Aluminum has been found to increase peroxidative damage to lipids, proteins and decreases antioxidant enzyme status [43]. On the other side, curcumin increased GSH content and decreased the level of lipid hydroperoxide in liver of rats injured by $\mathrm{CCl} 4$ [44]. Curcumin has been found to transact with oxidative stress in models of diabetes mellitus by increasing the activity of antioxidant enzymes such as superoxide dismutase 1 (SOD1), paraoxonase-1, glutathione peroxidase and catalase, which are main enzymes for the antioxidant preservation [45]. Treatment with curcumin increased GSH content in lymphocytes [46]. Soetikno et al. [47] found that treatment with curcumin prevented the decrease in GPx activity and decreased the oxidative stress, and renal fibrosis by modifing the normal pathway Nrf2-Keap1 in rats under nephrectomy. Curcumin showed ability to neutralize chemical carcinogens such as peroxyl, hydroxyl radical, superoxide and nitric oxide radical constitutes [48]. Curcumin-Nano partials showed excellent pharmacokinetics profiles compared to curcumin after a single oral dose of $50 \mathrm{mg} / \mathrm{kg}$ in rats [49]. The mean half-life of curcumin-Nano partials were $4 \mathrm{~h}$, while, the mean half-life of curcumin was $1 \mathrm{~h}$ [50]. Furthermore, Zhang et al. [51] found that curcumin nanoparticle markedly suppressed the oxidative stress in rats. Curcumin-NPs $(20 \mathrm{mg} / \mathrm{kg})$ significantly increased the activities of SOD, catalase and GPx, in rat compared with curcumin $(150,300 \mathrm{mg} / \mathrm{kg})$.

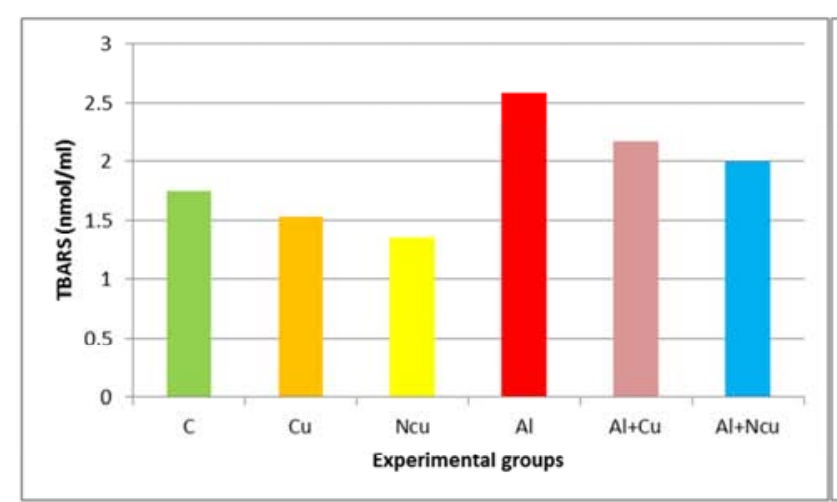

(A)

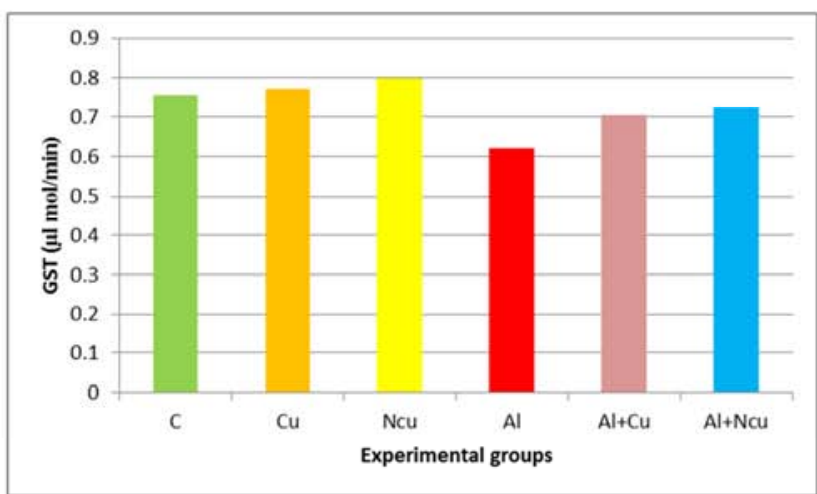

(C)

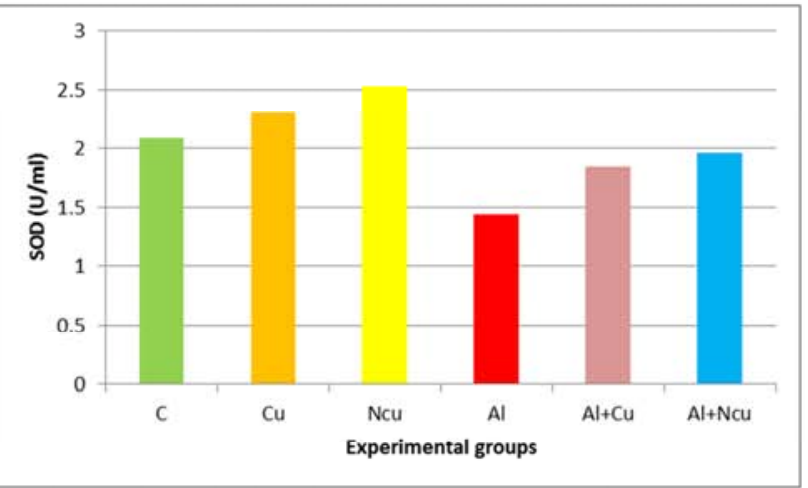

(B)

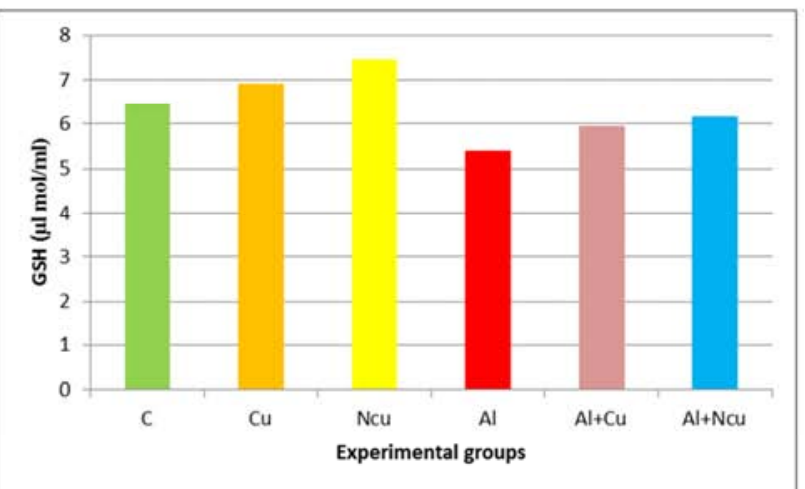

(D)

Figure 5. Effect of curcumin, nano curcumin on TBARS, antioxidant enzymes (SOD and GST) and GSH content in plasma of male rats treated with aluminum chloride.

$\mathrm{C}$ : Control, $\mathrm{Cu}$ : curcumin, $\mathrm{Ncu}$ : nano-curcumin, $\mathrm{Al}$ : aluminum chloride, $\mathrm{Al}+\mathrm{Cu}$ : aluminum chloride + curcumin and $\mathrm{Al}+\mathrm{Ncu}::$ aluminum chloride $+\mathrm{Nano}-$ curcumin 


\section{Conclusion}

Previous studies have suggested that aluminum plays a vital role in raising the signs of oxidative and inflammatory stress, which causes a strike in the nervous balance within the body. The results of the present study demonstrate that treating $\mathrm{AlCl}_{3}$ - treated rats with Curcumin and Nanocurcumin as antioxidant agents showed positive effects due to their ability to attenuate the reactivity of reactive oxygen species and to enhance activities of the antioxidant enzymes such as SOD and GST moreover the concentration of GSH. The present data showed that Curcumin and Nano-curcumin could be used to reduce the toxicity of $\mathrm{AlCl}_{3}$.

\section{Recommendations}

This study recommends the use of curcumin and curcumin nanoparticles in the production of functional foods because of their anti-toxic properties, especially due to aluminum, and also has an excellent antioxidant activity.

\section{Acknowledgements}

The authors are grateful to Prof. Mokhtar Ibrahim Yousef, Department of Environmental Studies, Institute of Graduate Studies and Research, Alexandria University, Egypt, for his support during the biological study. Also, we would like to thank Dr. Mahmoud Ibrahim El-Sayed, Department of Dairy Technology Research, Food Technology Research Institute, ARC, Giza, Egypt, for his help during writing and revision this manuscript.

\section{References}

[1] Nelson, K. M., Dahlin, J. L., Bisson, J., Graham, J., Pauli, G. F., Walters, M. A., 2017. The essential medicinal chemistry of curcumin miniperspective, J. Med. Chem. 60, 1620-1637.

[2] Shin, S. K., Ha, T. Y., McGregor, R. A., Choi, M. S., 2011. Longterm curcumin administration protects against atherosclerosis via hepatic regulation of lipoprotein cholesterol metabolism. Mol Nutr Food Res. 55, 18291840 .

[3] Anand, P., Kunnumakkara, A. B., Newman, R. A., Aggarwal, B. B., 2007. Bioavailability ofcurcumin: problems and promises, Mol. Pharm. 4, 807-818.

[4] Sultana, S., Khan, M. R., Kumar, M., Kumar, S., Ali, M., 2013. Nanoparticles-mediated drug delivery approaches for cancer targeting: a review. J Drug Target 21, 107-125.

[5] Laabbar, W., Elgot, A., Kissani, N., Gamrani, H., 2014. Chronic aluminum intoxication in rat induced both serotonin changes in the dorsal raphe nucleus and alteration of glycoprotein secretion in the subcommissural organ: immunohistochemical study. Neurosci. Lett. 577, 72-76.

[6] Willhite, C. C., Karyakina, N. A., Yokel, R. A., Yenugadhati, N., Wisniewski, T. M., Arnold, I. M., Momoli, F., Krewski, D., 2014. Systematic review of potential health risks posed by pharmaceutical, occupational and consumer exposures to metallic and nanoscale aluminium, aluminium oxides, aluminium hydroxide and its soluble salts. Crit. Rev. Toxicol. 44 (Suppl. 4), 1-80.

[7] Amjad, S. and Umesalma, S., 2015. Protective effect of Centella asiatica against aluminium-induced neurotoxicity in cerebral cortex, striatum, hypothalamus and hippocampus of rat brain- histopathological, and biochemical approach, J. Mol. Biomark. Diagn. 6: 212. doi: 10.4172/2155-9929.1000212.

[8] Krewski, D., Yokel, R. A., Nieboer, E., Borchelt, D., Cohen, J., Harry, J, et al., 2007. Human health risk assessment for aluminium, aluminium oxide, and aluminium hydroxide. J. Toxicol. Environ. Health, 10 (1), 1-269.

[9] Mai, S., Qin, H., Hong, W., Hu, X., Luo, Y., Yang, Y., Kuang, S., Tian, X., Ma, J., Yang, J. 2016. Toxicol. Appl. Pharmacol. $305,259-266$.

[10] Shoenfeld, Y., Agmon-Levin, N., 2011. 'ASIA' autoimmune/inflammatory syndrome induced by adjuvants. J. Autoimmun. 36, 4-8.

[11] Bondy, S. C., 2016. Low levels of aluminium can lead to behavioral and morphological changes associated with Alzheimer's disease and age-related neurodegeneration. Neurotoxicology 52, 222-229.

[12] Mahieu, S., Contini, M. C., Gonzalez, M., 2000. Aluminum toxicity, heatological effects. Toxicol. Lett. 111, 235-242.

[13] Chiroma, S. M., Moklas, M. A. M., Taib, C. N. M., Baharuldin, M. T. H., Amon, Z., 2018. D-galactose and aluminium chloride induced rat model with cognitive Impairments. Biomedicine \& Pharmacotherapy 103, 16021608.

[14] Childs, A. C., Phaneuf, S. L., Dirks, A. J., Phillips, T., Leeuwenburgh, C., 2002. Doxorubicin treatment in vivo causes cytochrome $\mathrm{C}$ release and cardiomyocyte apoptosis, as well as increased mitochondrial efficiency, superoxide dismutase activity, and Bcl-2: Bax ratio. Cancer Res. 62, 4592-4598.

[15] Kushwaha, P., Yadav, A., Samim, M. Flora, S. J. S., 2018. Combinatorial drug delivery strategy employing nanocurcumin and nano-MiADMSA for the treatment of arsenic intoxication in mouse. Chemico-Biological Interactions 286, 78-87.

[16] Tabacco, A., Meiattinim, F., Moda, E., Tarli, P., 1979. Simplified enzymic/colorimetric serum urea nitrogen determination. Clin Chem. 25, 336-337.

[17] Burtis, C. A., Ashwood, E. R., Bruns, D. E., 1999. Serum total protein determination. In: Tietz textbook of clinical chemistry and molecular diagnostics, 3rd ed. AACC 1915-1916.

[18] Fabiny, D. L., Ertingshausen, G., 1971. Automated reactionrate method for determination of serum creatinine with cintrifiChem. Clin Chem. 17, 696-700.

[19] Reitman, S., Frankel, S., 1957. A colorimetric method for the determination of serum glutamic oxaloacetic and glutamic pyruvic transaminases. American Journal of Clinical Pathology 26, 56-63.

[20] Belfield, A., Goldberg, D. M., 1971. Revised assay for serum phenyl phosphatase activity using 4-amino-antipyrine. Enzyme 12, 561-573. 
[21] Kind, P. R. N., King, E. J., 1954. Estimation of Plasma Phosphatase by Determination of Hydrolysed Phenol with Amino-antipyrine. J. Clin. Path. 7, 322-326.

[22] Tappel, A. L., Zalkin, H., 1959. Inhibition of lipid peroxidation in mitochondria by vitamin E. Archives of Biochemistry and Biophysics 80, 333-336.

[23] Misra, H. P., Fridovich, I., 1972. The role of superoxide anion in the autoxidation of epinephrine and a simple assay for superoxide dismutase. J. Biolog. Chem. 247, 3170-3175.

[24] Habig, W. H., Pabst, M. J., Jakoby, W. B., 1974. Glutathione Stransferases. The first enzymatic step in mercapturic acid formation. Journal of Biological Chemistry 249, 7130-7139.

[25] Jollow, D. J., Mitchell, J. R., Zampaglione, N., Gillete, J. R., 1974. Bromobenzene- induced liver necrosis, protective role of Glutathione and evidence for 3,4-Bromobenzene oxide in the hepatotoxic metabolite. Pharmacology 11, 151-169.

[26] SAS, (1986). Statistical Analysis System. SAS User's Guide: Statistics, version 5 ed. SAS Inst. Inc., Cary, NC, USA.

[27] Kumar, S., 1998. Biphasic effect of aluminium on cholinergic enzyme of rat brain. Neurosci Lett. 248: 121-123.

[28] Abubakar, M. G., Taylor, A., Ferns, G. A. A., 2004. Regional accumulation of aluminium in the rat brain is affected by dietary vitamin E. Journal of Trace Elements in Medicine and Biology. 18, 53-59.

[29] Zhang, L. C., Li, X. W., Gu, Q. Y., Zhu, Y. Z., Zhao, H. S., Li, Y. F., Zhang, Z. G., 2011. Effects of subchronic aluminum exposure on serum concentrations of iron and iron-associated proteins in rats. Biol. Trace Elem. Res. 141, 246-253.

[30] Priest, N. D., 2004. The biological behaviour and bioavailability of aluminium in man, with special reference to studies employing aluminium-26 as a tracer: review and study update. J. Environ. Monit. 6, 375-403.

[31] You, L. G., Wu, Z. Z., Li, Y. F., Zhang, Y. F., Li, M. X., 2003. The effect of buganyangsui formula on erythrocytes immune and regulation function in mice with Alzheimer's disease following aluminum exposure. Chin. J. Trad. Med. Sci. Technol. 10, 209-210.

[32] Zhang, Q., Cao, Z., Sun, X., Zuang, C., Huang, W., Li, Y., 2016. Aluminum trichloride induces hypertension and disturbs the function of erythrocyte membrane in male rats. Biol. Trace Elem. Res. 171 (1), 116-123.

[33] Abdel-Wahhab, M. A., Aljawish, A., El-Nekeety, A. A., Abdel-Aiezm, S. H., Abdel-Kader, H. A. M., Rihn, B. H., Joubert, O., 2015. Chitosan nano particles and quercetinmodulate gene expression and prevent the genotoxicity of aflatoxin B1 in rat liver. Toxicol. Rep. 2, 737747.

[34] Ortega-Domínguez, B., Aparicio-Trejo, O. E., García-Arroyo, F. E., León-Contreras, J. C., Tapia, E., Molina-Jijón, E., Hernández-Pando, R., Sánchez-Lozada, L. G., BarreraOviedo, D., Pedraza-Chaverri, J., 2017. Curcumin prevents cisplatin-induced renal alterations in mitochondria bioenergetics and dynamic. Food Chem. Toxicol. 107, 373385 .

[35] Xu, F., Liu, Y., Zhao, H., Yu, K., Song, M., Zhu, Y., Li, Y., 2017. Aluminum chloride caused liver dysfunction and mitochondrial energy metabolism disorder in rat. Journal of
Inorganic Biochemistry, 174, 55-62.

[36] Pratt, D. S., Kaplan, M. M., 2000. Evaluation of abnormal liver-enzyme results in asymptomatic patients. N Engl J Med. 342 (17), 1266-1271.

[37] Turkez, H., Yousef, M. I., Geyikoglu, F., 2010. Propolis prevents aluminium-induced genetic and hepatic damages in rat liver. Food Chem. Toxicol. 48, 2741-2746.

[38] Abdel-Wahhab, M. A., Salman, A. S., Ibrahim, M. I. M., ElKady, A. A., Abdel-Aziem, S. H., Hassan, N. S., Waly. A. I., 2016. Curcumin nanoparticles loaded hydrogels protects against aflatoxin B1-induced genotoxicity in rat liver. Food and Chemical Toxicology 94, 159-171.

[39] Exley, C., 2004. The pro-oxidant activity of aluminium. Free Radic. Biol. Med. 36, 380-387.

[40] Ruiperez, F., Mujika, J. I., Ugalde, J. M., Exley, C., Lopez, X., Inorg, J., 2010. Pro-oxidant activity of aluminum: Promoting the Fenton reaction by reducing Fe(III) to Fe(II). Journal of Inorganic Biochemistry, 117, 118-123.

[41] Mendez-Alvarez, E., Soto-Otero, R., Hermida-Ameijeiras, A., Lopez-Real, A. M., Labandeira-Garcia, J. L., 2002. Biochim. Biophys. Acta 1586, 155-168.

[42] Bihaqi, S. W., Sharm, M., Singh, A. P., Tiwari, M., 2009. Neuroprotective role of Convolvulus pluricaulis on aluminium induced neurotoxicity in rat brain. Journal of Ethnopharmacology 124, 409-415.

[43] Julka, D., Gill, K. D., 1996. Altered calcium homeostasis: a possible mechanism of aluminium induced neurotoxicity. Biochemica Biophysica Acta 135, 47-54.

[44] Fu, Y., Zheng, S., Lin, J., Ryerse, J., Chen, A., 2008. Curcumin protects the rat liver from $\mathrm{CCl}_{4}$-caused injury and fibrogenesis by attenuating oxidative stress and suppressing inflammation, Mol. Pharmacol 73, 399-409.

[45] Assis, R., Arcaro, C., Gutierres, V., Oliveira, J., Costa, P., Baviera, A., Brunetti, I., 2017. Combined effects of curcumin and lycopene or bixin in yoghurt on inhibition of LDL oxidation and increases in HDL and paraoxonase levels in streptozotocin-diabetic rats. Int. J. Mol. Sci. 18, 332. https://doi.org/10.3390/ijms18040332.

[46] Srinivasan, M., Rajendra Prasad, N., Menon, V. P., 2006. Protective effect of curcumin on gamma-radiation induced DNA damage and lipid peroxidation in cultured human lymphocytes, Mutat. Res. 611, 96-103.

[47] Soetikno, V., Sari, F. R., Lakshmanan, A. P., Arumugam, S., Harima, M., Suzuki, K., et al., 2013. Curcumin alleviates oxidative stress, inflammation, and renal fibrosis inremnant kidney through the Nrf2-keap1 pathway, Mol. Nutr. Food Res. 57, 1649-1659.

[48] Jha, N. S., Mishra, S., Jha, S. K., Surolia, A., 2015. Antioxidant activity and electrochemical elucidation of the enigmatic redox behavior of curcumin and its structurally modified analogues. Electrochim. Acta 151, 574-583.

[49] Khalil, N. M., do Nascimento, F. C. F., Casa, D. M., Dalmolin, L. F., de Mattos, A. C., Hoss, I., Romano, M. A., Mainardes, R. M., 2013. Pharmacokinetics of curcumin-loaded PLGA and PLGA-PEG blend nanoparticles after oral administration in rats. Colloid Surf. B Biointerf. 101, 353-360. 
[50] Naksuriya, O., Okonogi, S., Schiffelers, R. M., Hennink, W. E., 2014. Review Curcumin nanoformulations: A review of pharmaceutical properties and preclinical studies and clinical data related to cancer treatment. Biomaterials $35,3365-3383$.
[51] Zhang, Z., Jiang, M., Fang, J., Yang, M., Zhang, S., Yin, Y, et al., 2017. Enhanced therapeutic potential of nano-curcumin against subarachnoid hemorrhage-induced blood-brain barrier disruption through inhibition of inflammatory response and oxidative stress. Mol. Neurobiol. 54, 1-14. http://dx. doi.org/10.1007/s12035-015-9635-y. 